\title{
Characterization of Coal Spoil Recovered from Coal Mine Drainage Water
}

\author{
Aninda Nafis Ahmed ${ }^{*}$, Md. Anwar Arfien Khan², Madhu Sudan Saha ${ }^{3}$, Sharmin Sultana ${ }^{3}$ \\ ${ }^{1}$ Pilot Plant and Process Development Centre (PP \& PDC), BCSIR, Dhaka, Bangladesh \\ ${ }^{2}$ Leather Research Institute (LRI), BCSIR, Savar, Dhaka, Bangladesh \\ ${ }^{3}$ Institute of Mining, Mineralogy and Metallurgy (IMMM), BCSIR, Joypurhat, Bangladesh \\ Email: *adhi88bd@yahoo.com
}

How to cite this paper: Ahmed, A.N., Khan, Md.A.A., Saha, M.S. and Sultana, S. (2017) Characterization of Coal Spoil Recovered from Coal Mine Drainage Water. Journal of Geoscience and Environment Protection, 5, 227-236.

https://doi.org/10.4236/gep.2017.511015

Received: October 24, 2017

Accepted: November 24, 2017

Published: November 27, 2017

Copyright $\odot 2017$ by authors and Scientific Research Publishing Inc. This work is licensed under the Creative Commons Attribution International License (CC BY 4.0).

http://creativecommons.org/licenses/by/4.0/

\begin{abstract}
Barapukuria Coal Mine situated in the district Dinajpur. Bangladesh is playing an important role in the economy of this country by the mining of top quality coal. With coal mining, mine waste is also generated called coal spoil. Coal spoil can impose environmental threat if not treated carefully. In contrast, it can also be converted to value added product. In the present work, coal spoils collected from Barapukuria coal mine drainage water were investigated to determine the quality of the samples by physico-chemical analysis (proximate and ultimate analysis) as well as by heating value determination. $50 \%$ of carbon was detected in the samples after elemental analysis, with sulfur content less than $0.4 \%$. Calorific value around $9300 \mathrm{btu} / \mathrm{lb}$ was obtained for the coal spoil. Moreover, moisture content, ash, volatile matter content and fixed carbon also provided fruitful information regarding the quality and economic prospect of the samples in comparison to the quality of Barapukuria coal.
\end{abstract}

\section{Keywords}

Coal Spoil, Calorific Value, XRF, XRD, Particle Size Analysis, Thermal Analysis

\section{Introduction}

Coal spoil (CS) is a coal mining waste generated during mining and beneficiation of coal in coal mine. It is composed of various types of minerals, rocks and carbonaceous materials depending on the quality of mine and process of mining [1]. CS may include coarse discard which may result from cutting roadways, underground development work in the mine; and fine particles generated from 
washing process. This CS can cause serious environmental pollution. Actually coal mining has drastically adverse environmental impacts, including interference with ground water, land subsidence, impact of water use on flows of rivers and consequential impact on other land-uses, mining wastes disposal, geological hazards, visible and aesthetic offenders, sometimes damaging infrastructure, and potential ecological havoc, among of which mining wastes disposal has less progress considering disposal methods, utilization of mining wastes and its impact on environment [2] [3] [4] [5] [6]. As a result mining method can be made sustainable by minimizing waste production. This can be achieved by reusing the waste in different sectors. Therefore waste reduction and reuse have recently become the most preferable methods in waste management. Reusing of coal spoil totally depends on the types of spoil.

Spoil containing high carbonaceous material can be used as fuel in power plant. But before waste utilization, it is necessary to categorize the spoil.

In Bangladesh, coal reserves have been discovered in Jamalganj, Barapukuria, Khalashpir, Dhighipara and Phulbari. Among these reserves, only Barapukuria is having underground mining operations with a geological reserve of 390 million tons [7]. This underground mining operation needs to pump out $1500 \mathrm{~m}^{3}$ of water per hour to avoid flooding inside the mine [8]. This water carries out 200 $\mathrm{mg}$ of coal spoil per liter. Precipitator is used to settle the spoil from drainage water. But tons of coal spoils per month still overflows with the drainage water that is discharged from the mine to the nearby areas. Due to lacking of improper mine waste water disposal and unknown data about the production and categories of coal mining wastes in Barapukuria, the environment is being ruined day by day. Drainage water containing CS is causing environmental pollution because most coal spoils are in tyrannically heavily loaded with heavy metals [9] with coal dust. Moreover, in dried conditions these fine particles can produce serious dusting problem. This spoil is used as fuel in domestic and small industries which may not be appropriate as per its quality. So, proper characterization of this spoil is required to upgrade this material for proper economic utilization, which eventually will reduce pollution. In this work, an attempt was made to characterize this coal spoil in order to find a solution of pollution problem and appropriate economic utilizations.

\section{Materials and Methods}

Initially, samples were collected from three different spots adjacent to Barapukuria coal mine co. Ltd. Samples were collected from the deposits of coal spoil which were made by local people collecting them from the channels that carry coal mine drainage water. Some coal samples were also collected for comparing between coal and coal spoil. These samples were then taken to laboratory and their moisture content, volatile matter, ash, fixed carbon were measured by respective ISO/ASTM methods. Calorific values of samples were determined by using Parr 6400 calorimeter. CHNS values of the samples were detected by elemental 
analyzer; Thermo Flash-2000 and particle size distribution was measured by laser based particle size analyzer, Microtrac 3500. Rigaku ZSX Primus XRF machine equipped with an end window $4 \mathrm{~kW}$ RH-anode X-ray tube was used for $\mathrm{XRF}$ analysis of the CS ash which was prepared by burning CS for two hours at $815^{\circ} \mathrm{C}$. The XRD pattern of CS were determined by Bruker D8 Advance diffractometer with $\mathrm{Cu} \mathrm{K} \alpha=1.5406$ angstrom. TG/DTA studies were performed by using SII EXTAR 6000, TG/DTA 6300.

\section{Results and Discussions}

The Barapukuria coal mining waste mainly comprises fine carbonaceous materials with clay. This material is washed and carried away with the mine drainage water. Figure 1(a) shows the view of coal mine drainage water running though the channel. This water carries the CS. Local people collect this CS from the channels and dump them along the road side for drying as indicated in Figure 1(b). Samples from three different spots were collected and were indicated as sample CS-1, CS-2 and CS-3 as shown in Figure 2. These were found as lumpy mass of fine particles.

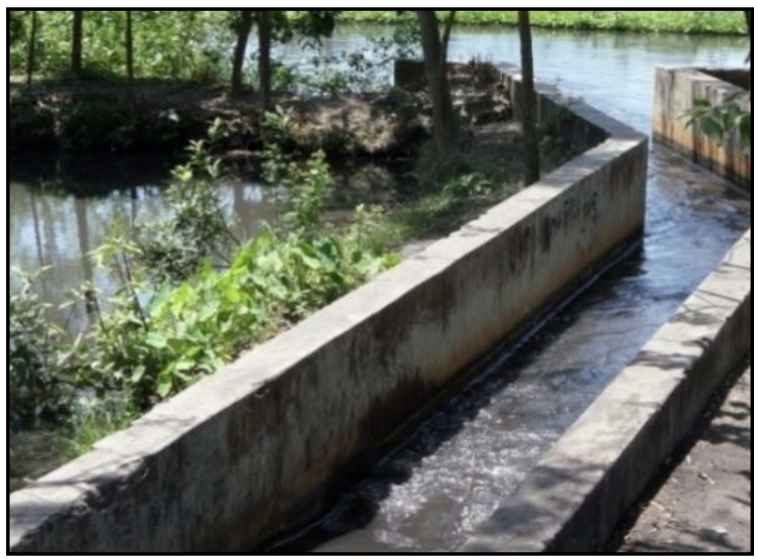

(a)

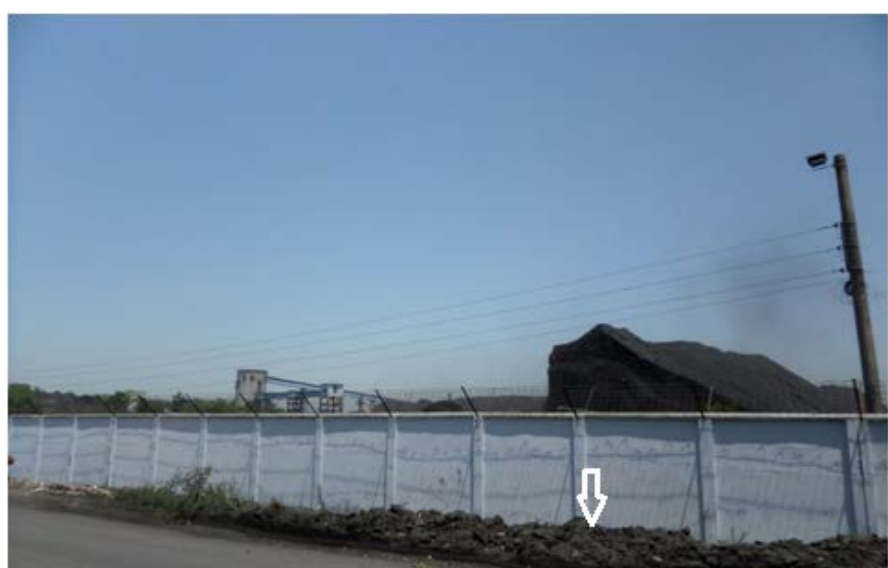

(b)

Figure 1. (a) Drainage water channel carrying coal spoil; (b) Coal spoil dumped along road side for drying (indicated by arrow). 


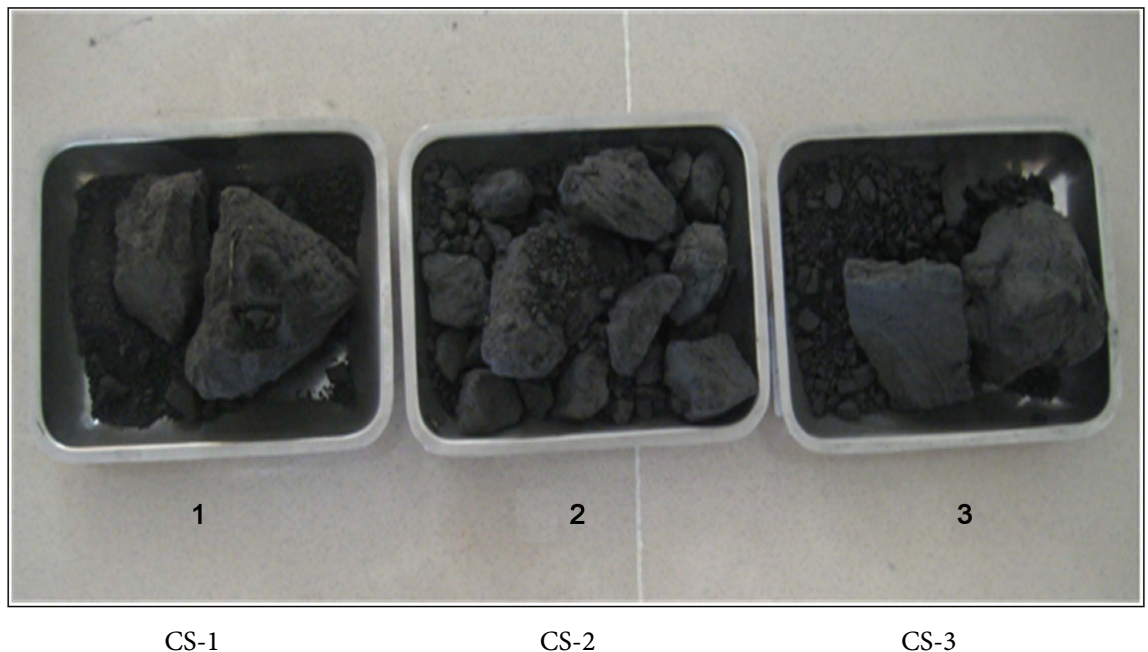

Figure 2. Collected coal spoil samples for laboratory analysis in the form of lumpy mass of fine particles.

\subsection{Proximate and Ultimate Analysis of CS}

Table 1 Shows the proximate analysis (wt\%) and heating value results of collected CS samples from Barapukuria coal mine sites. Lowest moisture content (as received) was found for sample CS- 1 nearly about $10 \%$ whereas, around $34.69 \%$ and $29.04 \%$ of moisture content (as received) was found for both CS-2 and CS-3 indicating that CS-1 was more dried than CS-2 and Cs-3. As earlier stated, samples are dumped at different places for air drying; CS-1 was collected in dried condition. However, CS-2 and CS-3 were collected in wet condition from sampling sites. In case of inner moisture content, all the samples had moisture content in between $2 \%$ to $3 \%$. Maximum inner moisture content was found for CS- 1 and it was $2.47 \%$ and minimum $2.34 \%$ for CS-3. These all are similar to the inner moisture content of Barapukuria Coal. Above $25 \%$ of volatile matter was found for CS-2, which was maximum, while CS-1 and CS-3 resulted around $24 \%$ and $24.5 \%$ of volatile matter respectively. The volatile matter of coal sample of Barapukuria was around $29.20 \%$ indicating that the lower volatile matter was found in CS in comparison to the Barapukuria coal. Maximum $35.5 \%$ ash was obtained from CS-1, whereas, nearly $30 \%$ ash was found for sample CS-2 and $31.5 \%$ for CS-3. On the other hand, Barapukuria coal had only $12.4 \%$ ash indicating that the experimental CS contains high metallic contaminant than Barapukuria coal. As a result heating value of experimental samples should be less than that of Barapukuria coal. Fixed carbon content of CS-1, CS-2 and CS-3 were shown $38.18 \%, 42.40 \%$ and $41.58 \%$, respectively which were near to the fixed carbon value of Barapukuria coal. Calorific values obtained from coal spoil were found a little less value than that of the coal of Barapukuria coal mine. Calorific value of Barapukuria coal was around 10,891 Btu/lb-11,040 Btu/lb while CS-1, CS-2 and CS-3 provided calorific values $9813.82 \mathrm{Btu} / \mathrm{lb}$, 9936.43 Btu/lb and $8145.35 \mathrm{Btu} / \mathrm{lb}$; respectively indicating that experimental CS has a little less heating capacity than that of Barapukuria coal; however this CS 
Table 1. Proximate analysis (wt\%) and calorific value (BTU/lb) of coal spoil.

\begin{tabular}{ccccc}
\hline Analyzing Parameters & CS-1 & CS-2 & CS-3 & Barapukuria coal \\
\hline Moisture (as received) & 9.17 & 34.69 & 29.04 & - \\
Inner-moisture & 2.47 & 2.39 & 2.34 & 2.37 \\
Ash content & 35.51 & 29.98 & 31.58 & 11.25 \\
Volatile matter & 23.84 & 25.23 & 24.5 & 31.08 \\
Fixed carbon & 38.18 & 42.4 & 41.58 & 55.34 \\
Calorific value & 9813.82 & 9936.43 & 8145.35 & 10,547 \\
\hline
\end{tabular}

has good potential for using as an energy fuel. Ultimate analysis of coal spoil is shown in Table 1. Around 50\% of carbon content was found from all of the coal spoil samples while Barapukuria coal had $68.72 \%$. Marginally higher carbon content was found in Barapukuria coal in comparison to the spoil. That is why; higher calorific value was obtained for Barapukuria coal. Sulfur content is a vital issue in case of coal quality as it is strongly connected with environmental pollution. Barapukuria coal has $0.32 \%-0.5 \%$ sulfur whereas maximum $0.43 \%$ sulfur was evident for CS-2, other two spoil samples CS-1 and CS-3 had similar result with that of coal (Table 2).

\subsection{Particle Size Distribution of CS}

As coal spoil was found as lumpy mass of fine particles, in dried condition it can produce serious dust problems. Particle size distribution of CS-1, CS-2 and CS-3 is shown in Figure 3. In each of the cases bimodal distribution was found for coal spoil samples with similar patterns. For CS-1, two major peaks were found around $20 \mu \mathrm{m}$ and $250 \mu \mathrm{m}$. CS- 2 showed peaks around $20 \mu \mathrm{m}$ and $220 \mu \mathrm{m}$ and CS-3 had peaks around $20 \mu \mathrm{m}$ and $300 \mu \mathrm{m}$. All the coal spoil samples had similar bimodal with micron size particles ranging from 2 to $1000 \mu \mathrm{m}$. These micron size particles can cause dust problem. However, having high carbon content and high calorific values, this dust can be utilized in coal fired thermal power plant as an alternative of pulverized coal.

\subsection{XRD Analysis of CS}

X-ray diffraction (XRD) patterns of CS-1, CS-2 and CS-3 are shown in Figure 4, which represents the main mineralogical phases of CS; graphite, quartz and kaolinite. The presence of graphite represents carbon and kaolinite represents clay indicating that the Barapukuria CS comprises with coal and clay.

\subsection{XRF Analysis of CS}

Chemical composition of coal spoil ash was analyzed after burning it at $850^{\circ} \mathrm{C}$ for two hours which is shown in Table 3. High concentrations of $\mathrm{SiO}_{2}, \mathrm{Al}_{2} \mathrm{O}_{3}$ and $\mathrm{Fe}_{2} \mathrm{O}_{3}$ were found in each sample. $3 \%$ of $\mathrm{TiO}_{2}$ were found in all the samples which are quite promising. Moreover, traces of heavy metals like $\mathrm{Cu}, \mathrm{Pb}, \mathrm{Zn}, \mathrm{Mn}$, 


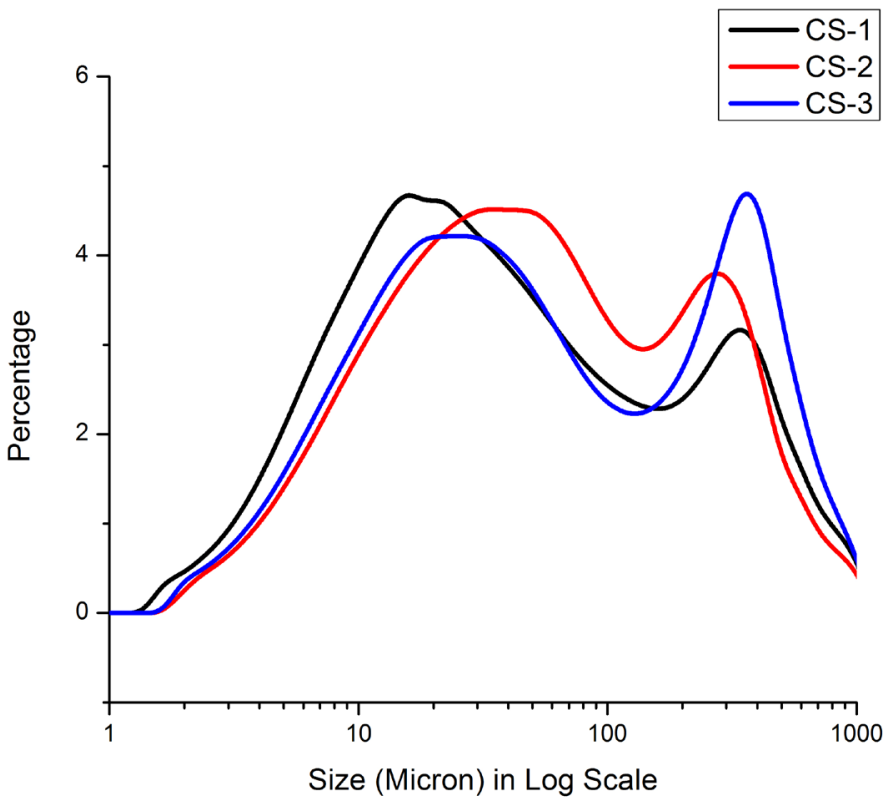

Figure 3. Particle Size Distribution of CS-1, CS-2 and CS-3

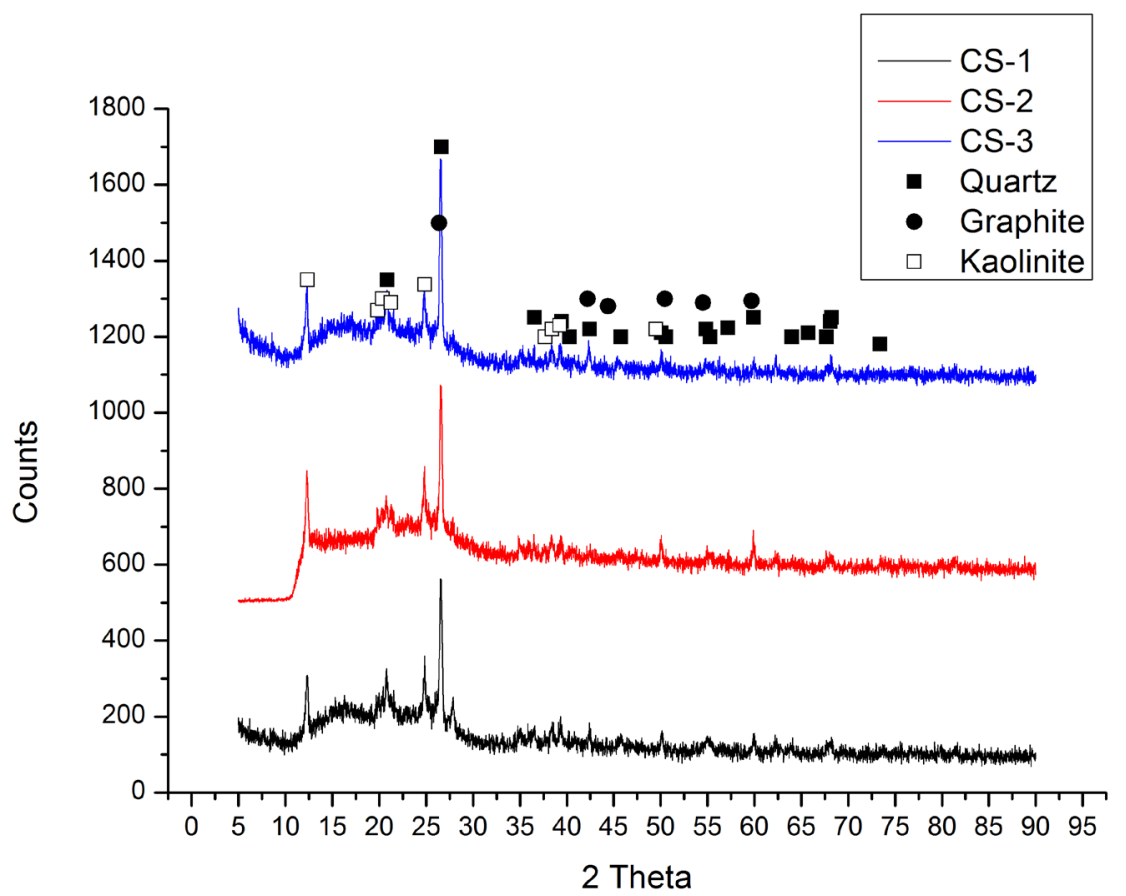

Figure 4. XRD patterns of CS-1, CS-2, and CS-3

Table 2. C, H, N, S analysis of coal spoil.

\begin{tabular}{ccccc}
\hline Sample & $\mathrm{C} \%$ & $\mathrm{H} \%$ & $\mathrm{~N} \%$ & $\mathrm{~S} \%$ \\
\hline CS-1 & 49.67 & 3.06 & 2.8 & 0.36 \\
CS-2 & 55.24 & 3.45 & 1.06 & 0.43 \\
CS-3 & 53.62 & 3.33 & 0.97 & 0.34 \\
Barapukuria coal & 68.72 & 4.31 & 0.92 & 0.32 \\
\hline
\end{tabular}


Table 3. Chemical analysis of coal spoils (wt\%) by X-RF.

\begin{tabular}{|c|c|c|c|c|c|c|}
\hline \multirow[b]{2}{*}{ Constituents } & \multicolumn{2}{|c|}{ CS-1 (wt\%) } & \multicolumn{2}{|c|}{ CS-2 (wt\%) } & \multicolumn{2}{|c|}{ CS-3 (wt\%) } \\
\hline & $\begin{array}{c}\text { Direct XRF } \\
\text { Analysis Data }\end{array}$ & $\begin{array}{l}\text { Calculated } \\
\text { Data on LOI }\end{array}$ & $\begin{array}{c}\text { Direct XRF } \\
\text { Analysis Data }\end{array}$ & $\begin{array}{c}\text { Calculated } \\
\text { Data on LOI }\end{array}$ & $\begin{array}{c}\text { Direct XRF } \\
\text { Analysis Data }\end{array}$ & $\begin{array}{c}\text { Calculated } \\
\text { Data on LOI }\end{array}$ \\
\hline $\mathrm{Na}_{2} \mathrm{O}$ & 0.173 & 0.116 & 0.083 & 0.058 & 0.135 & 0.093 \\
\hline $\mathrm{MgO}$ & 0.493 & 0.329 & 0.394 & 0.276 & 0.454 & 0.312 \\
\hline $\mathrm{Al}_{2} \mathrm{O}_{3}$ & 25.36 & 16.949 & 29.388 & 20.589 & 26.833 & 18.458 \\
\hline $\mathrm{SiO}_{2}$ & 55.722 & 37.241 & 47.086 & 32.988 & 53.994 & 37.141 \\
\hline $\mathrm{P}_{2} \mathrm{O}_{5}$ & 0.706 & 0.472 & 0.823 & 0.577 & 0.711 & 0.489 \\
\hline $\mathrm{SO}_{3}$ & 0.324 & 0.217 & 0.611 & 0.428 & 0.359 & 0.247 \\
\hline $\mathrm{Cl}$ & 0.009 & 0.006 & 0.042 & 0.029 & 0.016 & 0.011 \\
\hline $\mathrm{K}_{2} \mathrm{O}$ & 1.71 & 1.143 & 1.641 & 1.150 & 1.466 & 1.008 \\
\hline $\mathrm{CaO}$ & 1.679 & 1.122 & 2.326 & 1.630 & 1.842 & 1.267 \\
\hline $\mathrm{TiO}_{2}$ & 3.144 & 2.101 & 3.116 & 2.183 & 2.799 & 1.925 \\
\hline $\mathrm{Cr}_{2} \mathrm{O}_{3}$ & 0.276 & 0.184 & 0.337 & 0.236 & 0.321 & 0.221 \\
\hline $\mathrm{MnO}$ & 0.277 & 0.185 & 0.298 & 0.209 & 0.202 & 0.139 \\
\hline $\mathrm{Fe}_{2} \mathrm{O}_{3}$ & 9.589 & 6.409 & 13.033 & 9.131 & 10.348 & 7.118 \\
\hline $\mathrm{Co}_{2} \mathrm{O}_{3}$ & 0.018 & 0.012 & 0.023 & 0.016 & 0.011 & 0.008 \\
\hline $\mathrm{NiO}$ & 0.059 & 0.039 & 0.075 & 0.053 & 0.068 & 0.047 \\
\hline $\mathrm{CuO}$ & 0.017 & 0.011 & 0.039 & 0.027 & 0.021 & 0.014 \\
\hline $\mathrm{ZnO}$ & 0.06 & 0.040 & 0.101 & 0.071 & 0.062 & 0.043 \\
\hline $\mathrm{Ga}_{2} \mathrm{O}_{3}$ & 0.007 & 0.005 & - & - & 0.006 & 0.004 \\
\hline $\mathrm{Rb}_{2} \mathrm{O}$ & 0.009 & 0.006 & 0.012 & 0.008 & 0.009 & 0.006 \\
\hline $\mathrm{SrO}$ & 0.095 & 0.063 & 0.154 & 0.108 & 0.083 & 0.057 \\
\hline $\mathrm{Y}_{2} \mathrm{O}_{3}$ & 0.047 & 0.031 & 0.087 & 0.061 & 0.041 & 0.028 \\
\hline $\mathrm{ZrO}_{2}$ & 0.103 & 0.069 & 0.134 & 0.094 & 0.078 & 0.054 \\
\hline $\mathrm{BaO}$ & 0.096 & 0.064 & 0.151 & 0.106 & 0.122 & 0.084 \\
\hline $\mathrm{PbO}$ & 0.019 & 0.013 & 0.045 & 0.032 & 0.014 & 0.010 \\
\hline $\mathrm{ThO}_{2}$ & 0.004 & 0.003 & - & - & 0.004 & 0.003 \\
\hline LOI & - & 33.167 & - & 29.940 & - & 31.213 \\
\hline
\end{tabular}

$\mathrm{Cr}$, Co etc. were found in all categories of CS samples which indicate that, the trace heavy metals are released from the coal mine spoil into the environment.

\subsection{Thermal Analysis of CS}

The main minerals in the CS are graphite, quartz and kaolinite. Figure 5 shows the thermal analysis results of CS-1, CS-2 and CS-3. Figure 5(a) shows TGA graph of CS-1, CS-2 and CS-3 in which lowering of mass is evident by increasing temperature. CS-1, CS-2 and CS-3 gradually decreased their mass until $400^{\circ} \mathrm{C}$ at 


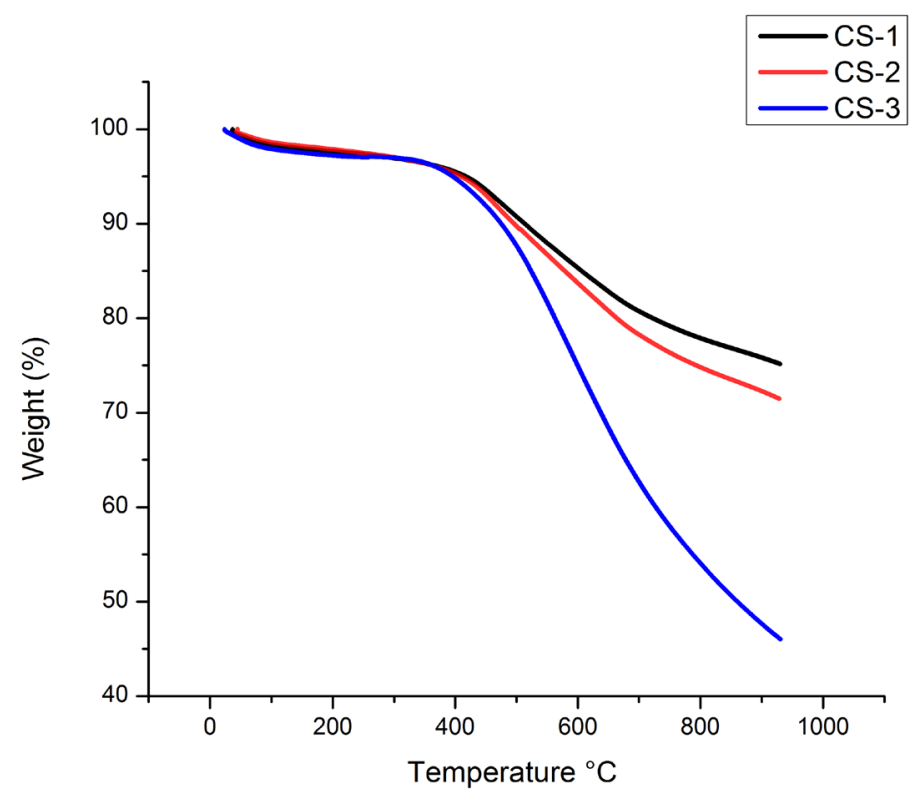

(a)

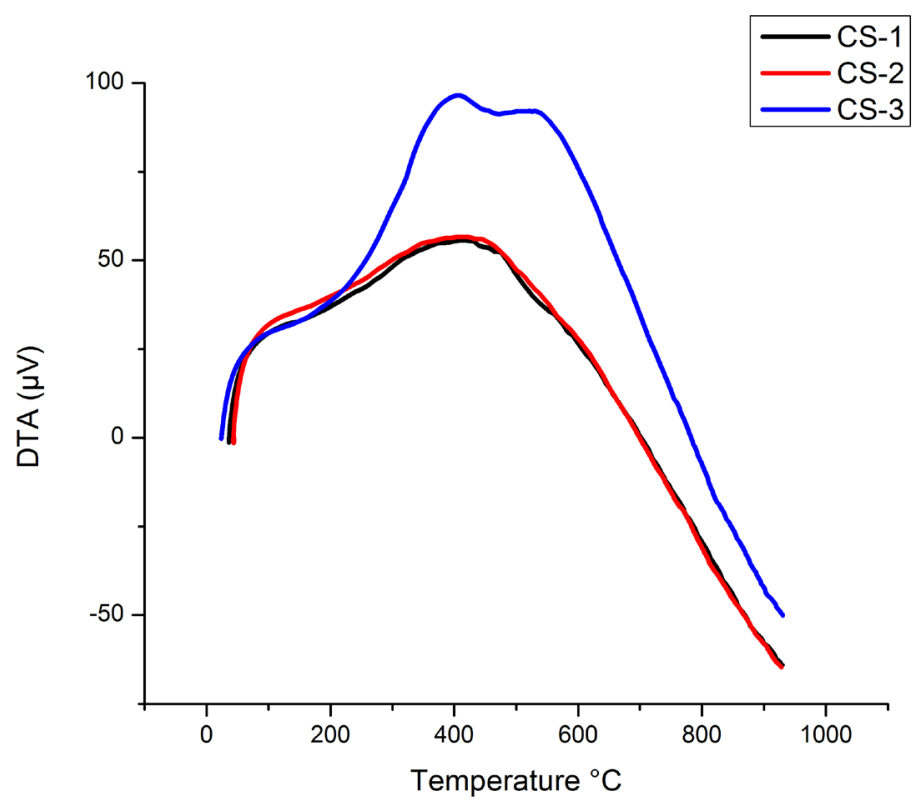

(b)

Figure 5. Thermal Analysis of CS-1, CS-2, and CS-3 (a) Thermogravimetric analysis; (b) Differential thermal analysis.

the same proportion, but at $400^{\circ} \mathrm{C}$ to $900^{\circ} \mathrm{C}$ CS-3 decreased it's mass rapidly than that of CS-2 and CS-1 indicating that the decomposition of CS- 3 was faster than that of CS-2 and CS-1 in a order of CS-3 > CS-2 > CS-1. On the other hand, Figure 5(b)) shows DTA results of CS-1, CS-2 and CS-3. The thermal analysis results in Figure 5(b) show two exothermic peaks at $400^{\circ} \mathrm{C}$ and $550^{\circ} \mathrm{C}$ appeared in CS-3. These are related with the combustion of volatile matter and fixed carbon, respectively. The two exothermic peaks of CS- 1 were found at $425^{\circ} \mathrm{C}$ and $480^{\circ} \mathrm{C}$. A broad exothermic peak appeared at $410^{\circ} \mathrm{C}$ for CS-2. No crystalline 
phase peak of kaolinite was appeared for CS-1, CS- 2 and CS-3 till $950^{\circ} \mathrm{C}$. These results indicated that the combustion of volatile matter and fixed carbon of CS-03 occurred rapidly than that of CS- 1 and CS-2.

\section{Conclusion}

Coal mining waste or coal spoil is an important issue for mine environmental protection. In this regard, characterization of mining waste is necessary for alternative utilization. In the present study, it was observed that Barapukuria coal mining waste mainly composed of high level carbonaceous materials. This material (CS) carries low sulfur content with high calorific value which is close to the coal of BCMCL. So, the CS of BCMCL can be used as a fuel in brick field and foundry industries as well as in thermal power plant for electricity generation. Further research in this field can be made in applied form to establish the economic prospect of coal spoil.

\section{Acknowledgements}

The work described here in this paper is funded by the R\&D assistance of Bangladesh Council of Scientific and Industrial Research (BCSIR), Ministry of Science and Technology, Govt. of Bangladesh. The authors are thankful to Dr. M A Gafur, Md. Rakibul Qadir and Sajib Aninda Dhar from PP\&PDC, BCSIR, Dhaka for their support. The authors are also grateful to Mst. Shanjida Sultana, Md Aminur Rahman, Dr. Md. Nazim Zaman from IMMM, BCSIR, Joypurhat and Mohammad Shah Jamal, from IFRD, BCSIR, Dhaka for their assistance.

\section{References}

[1] Si, P., Qiao, X.C., Luo, Y., Song, X.F. and Yu, J.G. (2009) Extraction of Aluminum from Combustion Ash of Coal Spoil. World of Coal Ash (WOCA) Conference, Lexington, KY, USA. http://www.flyash.info/2009/014-si2009.pdf

[2] Bian, Z.F., Wang, H., Mu, S.G. and Leng, H.L. (2007) International Conference "Waste Management, Environmental Geotechnology and Global Sustainable Development". Ljubljana, 28-30 August 2007.

[3] Bell, F.G., Staccy, T.R. and Genske, D.D. (2000) Mining Subsidence and Its Effect on the Environment: Some Differing Examples. Environmental Geology, 40, 135-152. https://doi.org/10.1007/s002540000140

[4] Mc Kinnon, E. (2002) The Environmental Effects of Mining Waste Disposal at Lihir Gold Mine, Papua New Guinea. Journal of Rural and Remote Environmental Health, 1, 40-50.

[5] Ripley, E.A. and Redmann, R.E. (1996) Environmental Effects of Mining. CRC Press, Boca Raton, 49-85.

[6] Bian, Z.F. and Zhang, Y. (2006) Land Use Changes in Xuzhou Coal Mining Area. Acta Geographica Sinica, 61, 349-358.

[7] Harun-or-Rashid, Hossain, Md.S., Urbi, Z. and Islam, Md.S. (2014) Environmental Impact of Coal Mining: A Case Study on the Barapukuria Coal Mining Industry, Dinajpur, Bangladesh. Middle-East Journal of Scientific Research, 21, 268-274. 
[8] Halim, M.A., Mazumder, R.K., Zaman, M.N., Hossain, S., Rasul, M.G. and Sasaki, K. (2013) Mobility and Impact of Trace Metals in Barapukuria Coal Mining Area, Northwest Bangladesh. Arabian Journal of Geoscience, 6, 4593-4605. https://doi.org/10.1007/s12517-012-0769-1

[9] Zhi, D., Haigh, M., Watts, S.F., Wan, G.J. and Li, D.R. (1996) Coal Mine Spoil-Water Interaction: Weathering Concentrated Metals in Surface Coal Mine Spoils. Science in China (Series D: Earth Sciences), 39, 610-617. 